\title{
Patient education for phosphorus management in chronic kidney disease
}

\author{
This article was published in the following Dove Press journal: \\ Patient Preference and Adherence \\ 2 May 2013 \\ Number of times this article has been viewed
}

\section{Kamyar Kalantar-Zadeh \\ Harold Simmons Center for Kidney Disease Research and Epidemiology, Division of Nephrology and Hypertension, University of California Irvine's School of Medicine, Irvine, CA, USA}

Objectives: This review explores the challenges and solutions in educating patients with chronic kidney disease (CKD) to lower serum phosphorus while avoiding protein insufficiency and hypercalcemia.

Methods: A literature search including terms "hyperphosphatemia," "patient education," "food fatigue," "hypercalcemia," and "phosphorus-protein ratio" was undertaken using PubMed.

Results: Hyperphosphatemia is a strong predictor of mortality in advanced CKD and is remediated via diet, phosphorus binders, and dialysis. Dietary counseling should encourage the consumption of foods with the least amount of inorganic or absorbable phosphorus, low phosphorus-to-protein ratios, and adequate protein content, and discourage excessive calcium intake in high-risk patients. Emerging educational initiatives include food labeling using a "traffic light" scheme, motivational interviewing techniques, and the Phosphate Education Program whereby patients no longer have to memorize the phosphorus content of each individual food component, but only a "phosphorus unit" value for a limited number of food groups. Phosphorus binders are associated with a clear survival advantage in CKD patients, overcome the limitations associated with dietary phosphorus restriction, and permit a more flexible approach to achieving normalization of phosphorus levels.

Conclusion: Patient education on phosphorus and calcium management can improve concordance and adherence and empower patients to collaborate actively for optimal control of mineral metabolism.

Keywords: hyperphosphatemia, renal diet, phosphorus binders, educational programs, food fatigue, concordance

\section{Introduction}

Chronic kidney disease (CKD) is associated with an increased risk of cardiovascular disease (CVD) and mortality. ${ }^{1}$ This increased mortality is related to traditional cardiovascular (CV) risk factors such as diabetes and hypertension, which are common comorbidities, but is also related to disorders of bone and mineral metabolism (renal osteodystrophy) and vascular calcification. This led to the concept of CKD-mineral bone disorder (CKD-MBD), which describes a systemic disorder characterized by laboratory abnormalities (calcium, phosphorus, parathyroid hormone [PTH], and vitamin D), bone abnormalities, and vascular calcification. A strong association exists between elevated serum phosphorus $(>5.0 \mathrm{mg} / \mathrm{dL})$ and calcium $(>9.5 \mathrm{mg} / \mathrm{dL})$ and mortality in dialysis patients, reflecting a preponderance of CVD-related deaths. ${ }^{2,3}$ Increased CV risk with hyperphosphatemia and hypercalcemia is also evident in the general population. ${ }^{4}$ Studies have also shown that hyperphosphatemia is associated with increased 
vascular stiffening $^{5}$ and arterial $^{6}$ and valvular calcification. ${ }^{7}$ This is postulated to be caused by elevated serum phosphorus promoting the transformation of vascular smooth muscle cells into an osteoblast phenotype that can mineralize. ${ }^{8}$

Of all the components of CKD-MBD, hyperphosphatemia conveys the highest risk of death $(\sim 12 \%)$ in hemodialysis patients, which is increased further once hypercalcemia and elevated PTH are considered (17.5\%). ${ }^{2}$ A higher dietary intake of phosphorus and higher phosphorus-to-protein ratio are both associated with increased risk of mortality in hemodialysis patients, even after adjustment for serum phosphorus and phosphorus binders, dietary protein, energy, and potassium intake (Figure 1). ${ }^{9}$ Efforts to reduce morbidity and mortality associated with CKD-MBD are therefore primarily directed at controlling hyperphosphatemia via diet, phosphorus binders, and dialysis. The goal in patients with end stage renal disease (ESRD) is to maintain a low intake of phosphorus (ideally $700 \mathrm{mg} /$ day) while maintaining adequate protein intake. ${ }^{10}$

Phosphorus is found in almost every food and is derived primarily from proteins, ${ }^{10}$ phytates, ${ }^{11}$ and additives. ${ }^{12,13}$ Two types exist - organic and inorganic - depending on the dietary source. Inorganic phosphorus is present in processedfood additives, ${ }^{11}$ which are highly absorbable, and is highly abundant in the diet of postmodern industrialized regions. ${ }^{14}$ Organic phosphorus is found in animal- and plant-derived protein-rich foods; however, the phosphorus-to-protein ratio differs markedly depending on the food source. ${ }^{15}$

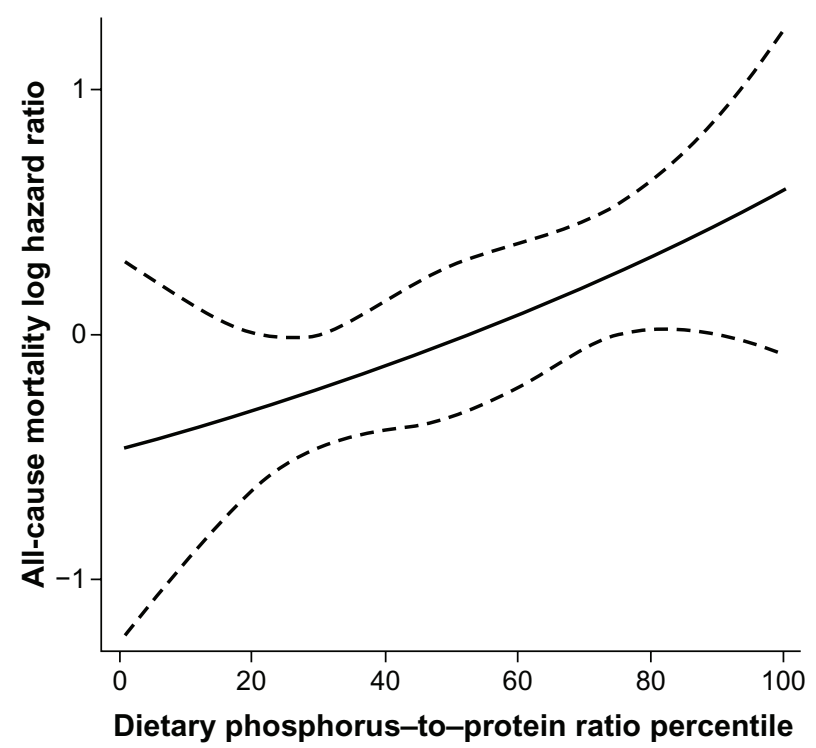

Figure I A high phosphorus/protein ratio increases mortality risk in CKD patients even after adjustment for binders, serum phosphorus, and diet. Noori N, Kalantar-Zadeh K, Kovesdy CP, Bross R, Benner D, Kopple JD. Association of dietary phosphorus intake and phosphorus to protein ratio with mortality in hemodialysis patients. Clin J Am Soc Nephrol. 2010;5(4):683-692.' @ American Society of Nephrology 2010.

Abbreviation: CKD, chronic kidney disease.
Although plant proteins also contain phosphorus, much plant phosphorus is in the form of less-absorbable phytates. ${ }^{13}$ While it is important to minimize the dietary phosphorus burden, a high dietary protein intake should be maintained in dialysis patients to avoid protein wasting and improve survival. ${ }^{16}$ Balancing dietary phosphorus and protein intake is best achieved using the phosphorus-to-protein ratio to select protein sources with the least serum phosphorus "cost." 15 In addition to dietary intervention, phosphorus binders lower serum phosphorus by reducing the absorption of dietary phosphorus from the gut. They are indicated in the US for hyperphosphatemic dialysis recipients; in certain other countries, they are indicated for hyperphosphatemic patients with CKD stages $3-5$ or on dialysis. ${ }^{17}$

Achieving the recommended serum phosphorus levels using diet and phosphorus binders requires patient comprehension and active participation as well as adherence and persistence. In particular, practitioners need to communicate the consequences (especially mortality risk) of hyperphosphatemia in CKD-MBD. For example, clinicians should explain the consequences of patients' behavior (eg, consuming a cola drink high in phosphorus needs to be accompanied by a binder). Given the complex pathologies and treatment regimen associated with CKD-MBD, close collaboration among the different members of the renal team and the patient is important in order to develop individualized treatment plans that fit patients' lives and will improve adherence over time. Patient education and concordance can improve implementation of regimens for phosphorus control in CKD-MBD.

This review will examine challenges and solutions in educating patients with ESRD to lower serum phosphorus while avoiding protein insufficiency and hypercalcemia.

\section{Phosphorus control methods - diet, binders, and dialysis Dietary phosphorus}

Three sources of dietary phosphorus exist: (1) Organic phosphorus present in plant foods (eg, phytates); (2) Organic phosphorus present in animal protein (eg, casein); and (3) Inorganic phosphorus (eg, additives in processed food). Because humans lack the degrading enzyme phytase, phosphorus in plant foods (seeds, nuts, legumes) has a low bioavailability (20\%-40\%). In contrast, the phosphorus in animal-derived food has a higher bioavailability ( $40 \%-60 \%)$ because it is easily hydrolyzed and absorbed. Inorganic phosphorus is the most readily absorbable with a bioavailability of approximately $100 \% .^{12,13}$ Overconsumption of bioavailable inorganic phosphorus in food additives 
and preservatives contributes to hyperphosphatemia for patients with CKD. Thus, practitioners need to educate patients on the differences in phosphorus bioavailability. Phosphorus additives are abundant in cheap processed and fast foods, ${ }^{11}$ which is reflected in the higher phosphorus intake observed in lower socioeconomic groups. ${ }^{18}$ Inorganic phosphorus additive intake in the USA rose dramatically between the 1970s and 1990s ${ }^{19}$ and may contribute as much as $1000 \mathrm{mg} /$ day to the average American diet. ${ }^{14}$ Environmental differences can also affect the phosphorus content in certain food sources. For instance, the phosphorus content in farm-raised fish is higher than in wild fish due to exposure to higher dietary phosphorus and environmental factors that influence final mineral content. ${ }^{20}$

The majority of dietary phosphorus is derived from protein. The recommended daily intake is $700 \mathrm{mg}$ of phosphorus per day for CKD patients, ${ }^{21}$ though the usual intake ranges between 1000-2000 mg/day. ${ }^{10}$ However, given the difference in bioavailability of organic and inorganic phosphorus, predictions of phosphorus intake should not be based solely on protein intake. Furthermore, the restriction of poorly absorbed foodborne organic phosphorus is unnecessary; overzealous restriction of protein-associated phosphorus may even contribute to protein malnutrition with an adverse impact on survival. ${ }^{22}$

Previous methods for estimating phosphorus content significantly underestimated phosphorus content by $15 \%$ to $25 \%,{ }^{23}$ which emphasizes the need for more information via food frequency questionnaires, food tables, and nutritional databases on phosphorus content and bioavailability, phosphorus-protein ratios, and additives. The selection of appropriate foods low in phosphorus is hindered by the fact that food manufacturers are not required to list the phosphorus content on food labels. ${ }^{24}$ Furthermore, inorganic phosphorus is often hidden by complex names in ingredients (eg, disodium monophosphate; Table 1). ${ }^{25}$ Additionally, dialysis patients have a higher normalized protein catabolic rate than healthy persons, which results in endogenously increased inorganic phosphorus levels and higher binder requirements. ${ }^{26} \mathrm{~A}$ strong association exists between dietary protein and phosphorus intake. The following regression equation was able to account for $83 \%$ of the variance in dietary phosphorus intake (Figure 2): ${ }^{12}$

$$
\text { Dietary phosphorus } \begin{aligned}
(\mathrm{mg})= & 78+11.8 \\
& \times \text { protein intake }(\mathrm{g})
\end{aligned}
$$

The phosphorus-to-protein ratio has several advantages as a dietary metric: it is (1) independent of size of food portion; (2) focused on dietary protein and phosphorus intake; (3) higher for foods with unusually high amounts of phosphorus; and (4) a way of identifying foods high in phosphorus. ${ }^{9}$ A limitation of absolute phosphorus content and phosphorus-to-protein ratio is

\begin{tabular}{|c|c|c|}
\hline Phosphate salt & Purpose & Foodstuffs \\
\hline Dicalcium phosphate & $\begin{array}{l}\text { Calcium and phosphorus supplement, } \\
\text { dough conditioner }\end{array}$ & $\begin{array}{l}\text { Bakery mixes, cereals, flour, food bars, } \\
\text { infant food, yogurt }\end{array}$ \\
\hline Disodium phosphate & $\begin{array}{l}\text { Sequestrant, emulsifier, buffering agent, absorbent, } \\
\mathrm{pH} \text { control agent, protein modifier, source } \\
\text { of alkalinity, stabilizer }\end{array}$ & $\begin{array}{l}\text { Breakfast cereal, cheese, condensed milk, } \\
\text { flavored milk powders, ice cream, isotonic } \\
\text { drinks, pasta, processed cheese, vitamin } \\
\text { capsules }\end{array}$ \\
\hline Monosodium phosphate & $\begin{array}{l}\text { Acidulant, buffering agent, emulsifier, leavening agent, } \\
\text { protein modifier and sequestrant, gelling agent }\end{array}$ & $\begin{array}{l}\text { Cola beverages, dry powder beverages, } \\
\text { egg yolks, gelatin, instant cheesecake, } \\
\text { instant pudding, isotonic beverages }\end{array}$ \\
\hline Phosphoric acid & $\begin{array}{l}\text { Acidulant, pH control agent, buffering agent, flavor } \\
\text { enhancer, flavoring agent, sequestrant, stabilizer }\end{array}$ & $\begin{array}{l}\text { Cola beverages, carbonated and } \\
\text { noncarbonated beverages }\end{array}$ \\
\hline Sodium hexametaphosphate & $\begin{array}{l}\text { Sequestrant, curing agent, dough strengthener, } \\
\text { emulsifier, firming agent, flavor enhancer, humectant, } \\
\text { stabilizer, thickener }\end{array}$ & $\begin{array}{l}\text { Meat, seafood, poultry, vegetables, } \\
\text { cream, ice cream, whey, processed } \\
\text { cheese, eggs, table syrups, toppings }\end{array}$ \\
\hline Sodium tripolyphosphate & $\begin{array}{l}\text { Sequestrant, pH control agent, emulsifier, source } \\
\text { of alkalinity, buffering agent, coagulant, dispersing agent, } \\
\text { antioxidant, curing agent, flavor enhancer, humectant }\end{array}$ & $\begin{array}{l}\text { Meat products, seafood, poultry, vegetable } \\
\text { proteins, processed cheese, sour cream, } \\
\text { dips, yogurt, eggs, table syrups }\end{array}$ \\
\hline Tetrasodium pyrophosphate & $\begin{array}{l}\text { Buffering agent, pH control agent, source of alkalinity, } \\
\text { dispersing agent, coagulant, sequestrant, color stabilizer }\end{array}$ & $\begin{array}{l}\text { Processed meat, poultry, seafood, processed } \\
\text { cheese, potato products, ice cream, } \\
\text { frozen desserts }\end{array}$ \\
\hline Trisodium phosphate & $\begin{array}{l}\text { Buffer, emulsifying agent, stabilizer, protein modifier, } \\
\mathrm{pH} \text { control, color stabilizer }\end{array}$ & $\begin{array}{l}\text { Processed cheese, cheese products, isotonic } \\
\text { beverages, cooked breakfast cereals }\end{array}$ \\
\hline
\end{tabular}

Table I Common phosphorus additives used by the food industry

Reprinted with permission Kalantar-Zadeh K, Gutekunst L, Mehrotra R, et al. Understanding sources of dietary phosphorus in the treatment of patients with chronic kidney disease. Clin J Am Soc Nephrol. 2010;5(3):519-530.12 (C) American Society of Nephrology 2010. 

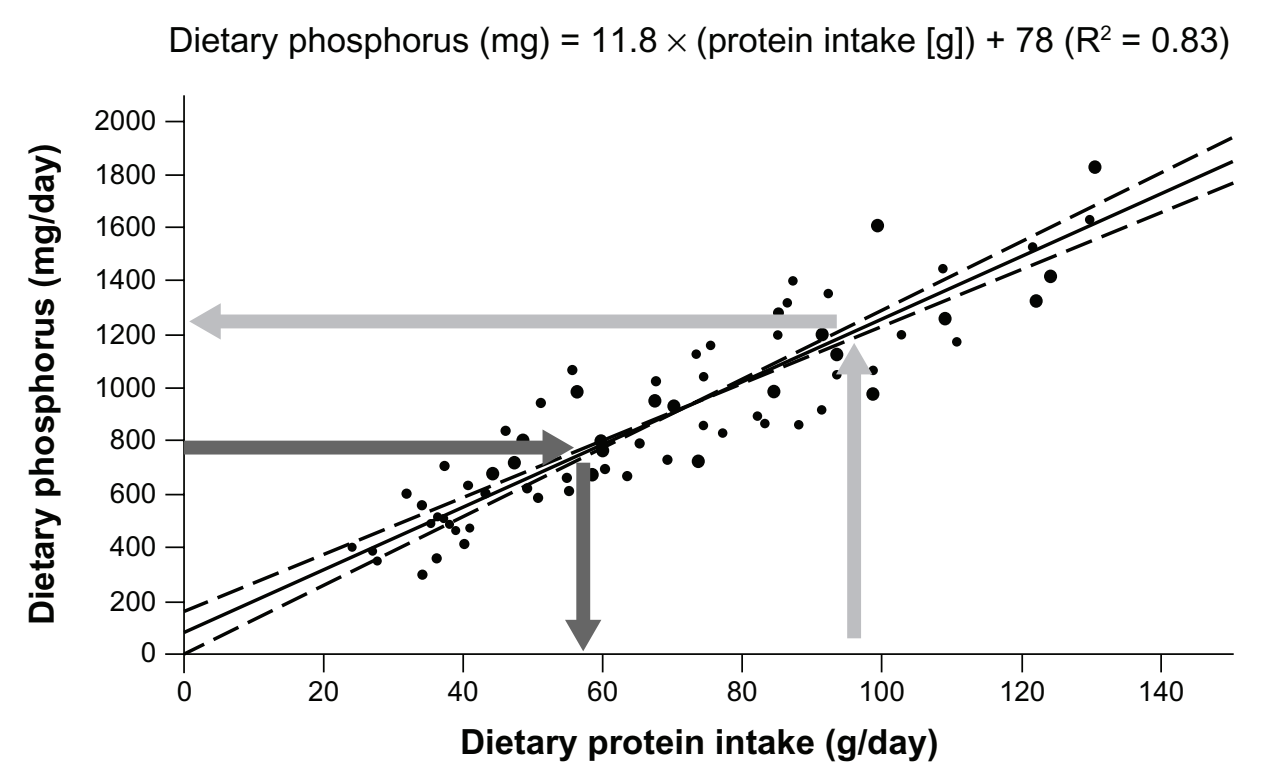

Figure 2 Dietary phosphorus can be estimated using a regression equation that accounts for $83 \%$ of the variance and demonstrates the strong association between dietary phosphorus and protein intake. Repinted with permission Kalantar-Zadeh K, Gutekunst L, Mehrotra R, et al. Understanding sources of dietary phosphorus in the treatment of patients with chronic kidney disease. Clin J Am Soc Nephrol. 2010;5(3):519-530.I 2 @ American Society of Nephrology 2010.

their lack of information about bioavailability in different food types. ${ }^{9}$

In summary, dietary phosphorus is strongly related to protein content, but is unreliably estimated due to differences in bioavailability and the presence of inorganic phosphorus in additives. Despite these barriers, patient education and concordance can improve the implementation of an effective diet and binder regimen to control phosphorus in the CKD-MBD patient. ${ }^{27}$

\section{Phosphorus binders}

Dietary restriction and dialysis are usually insufficient to maintain phosphorus within the recommended range (2.7$5.5 \mathrm{mg} / \mathrm{dL}$ ) in patients with CKD. Since their introduction over 30 years ago, phosphorus binders have been used to optimize the management of hyperphosphatemia and lower serum phosphorus to within target levels. Their importance is exemplified by a recent study showing a clear survival advantage in predialysis CKD patients using any binders versus no binder (Figure 3). ${ }^{28}$ Aluminum-containing binders were the first to be introduced, but their use has been restricted due to the incidence of osteomalacia and encephalopathy, ${ }^{17}$ they are now generally reserved for rescue therapy where hyperphosphatemia is accompanied by highly elevated PTH and serum calcium levels. Calcium-based binders (calcium carbonate and calcium acetate) subsequently became widely used, but there are also growing safety concerns related to excessive total body calcium, which can induce adynamic bone disease and increase the risk of $\mathrm{CV}$ and soft tissue calcification. ${ }^{29}$
Where there is evidence of hypercalcemia or calcification in predialysis and dialysis patients with $\mathrm{CKD}$, Kidney Disease: Improving Global Outcomes (KDIGO) recommends restricting the dose of these binders. ${ }^{17}$ Vascular calcification is highly prevalent in predialysis $(40 \%)^{30}$ and dialysis patients $(88 \%),{ }^{31}$ and it is therefore possible that some patients would benefit from the use of calcium-free binders such as sevelamer carbonate/hydrochloride or lanthanum carbonate, which may reduce the risk of hypercalcemia and its consequences. ${ }^{32,33}$ Some studies suggest that the choice of binder in hemodialysis patients can affect the mortality rate ${ }^{34,35}$ however, further studies are warranted to confirm any survival advantage for specific binders (Figure 4). ${ }^{34}$ The Dialysis Clinical Outcomes Revisited (DCOR) study compared any-cause and cause-specific mortality between sevelamer and calcium binder recipients on prevalent dialysis. In the overall DCOR population, mortality endpoints did not differ between binder groups; however, sevelamer was associated with lower allcause mortality compared with calcium binders in patients aged 65 years and older. ${ }^{35}$

\section{Dialysis}

Optimal dialysis still requires combination with individualized dietary guidance and binder use to normalize serum phosphorus levels. In general, dialyzer clearance is dependent on an effective blood flow rate (eg, 250-300 mL/minute), which initially improves the clearance of phosphorus. However, serum phosphorus levels plateau after about 2 hours of dialysis; during the second half of treatment, 


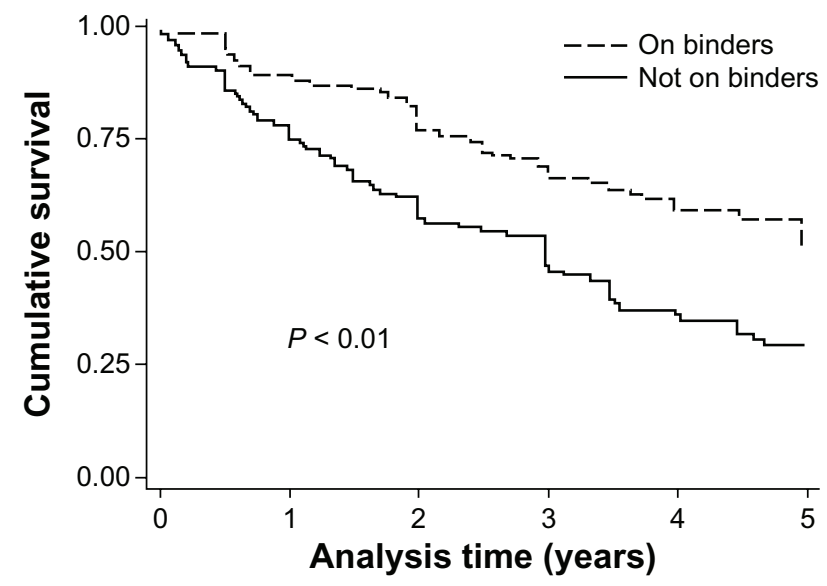

Figure 3 The use of phosphorus binders has a significant survival benefit in veterans $(n=1188)$ with moderate to advanced CKD. Reprinted with permission Kovesdy CP, Kuchmak O, Lu JL, Kalantar-Zadeh K. Outcomes associated with phosphorus binders in men with non-dialysis-dependent CKD. Am J Kidney Dis. 2010;56(5):842-85। . ${ }^{28}$ C) Elsevier 2010. Abbreviation: CKD, chronic kidney disease.

serum phosphorus does not decline any further and may actually increase again. ${ }^{36}$ This rebound effect is due to the mobilization of intracellular phosphorus, which compensates for the increased clearance of phosphorus. ${ }^{37}$ Optimal clearance of phosphorus is dependent on the timing and duration of dialysis. Long nocturnal hemodialysis is associated with increased phosphorus removal and decreased phosphorus binder requirements compared with conventional hemodialysis. ${ }^{38}$ Limitations in phosphorus clearance are inherent in both hemodialysis and peritoneal dialysis, although the latter is less dependent on dialyzer clearance of urea and correlates better with creatinine clearance. Phosphorus clearance using peritoneal dialysis is also influenced by peritoneal membrane transport characteristics and modality (eg, continuous versus intermittent). ${ }^{39}$ Dialysis therapy is therefore limited in its ability to control phosphorus. Dialysis recipients need to closely control phosphorus intake rather than rely solely on dialytic phosphorus elimination. Patients with CKD prior to dialysis also need phosphorus management to reduce the cumulative biochemical impact of processes required to maintain phosphorus excretion as kidney function declines. Thus, efforts to improve patient education are directed at dietary intervention at all stages of $\mathrm{CKD}$, and binder use at stages with locally approved indications.

\section{New approaches to dietary phosphorus control}

Dietary phosphorus control is appropriate at any stage of CKD. Whereas 20 years ago dietitians emphasized controlling phosphorus by restricting protein, current recommendations focus on controlling phosphorus by reducing additives and seeking natural, unprocessed, low-phosphorus protein sources, as it is well-established that reducing protein intake may lead to protein-energy wasting and impaired survival. ${ }^{22}$ Paradoxically, increasing protein intake also worsens the survival rate in hemodialysis patients unless this is accompanied by reduced phosphorus intake. ${ }^{22}$ The lowest amount of phosphorus in proportion to protein comes from nondairy products and animal-derived foods, including egg whites and pork rinds (Table 2). ${ }^{13}$ Egg white is an unusually rich source of high biological value protein and has one of the lowest phosphorus-to-protein ratios, and is devoid of cholesterol, making it an ideal dietary choice for the CKD patient. This is supported by the results of a pilot study which showed that consuming egg whites as a primary protein source in maintenance hemodialysis patients effectively lowered serum

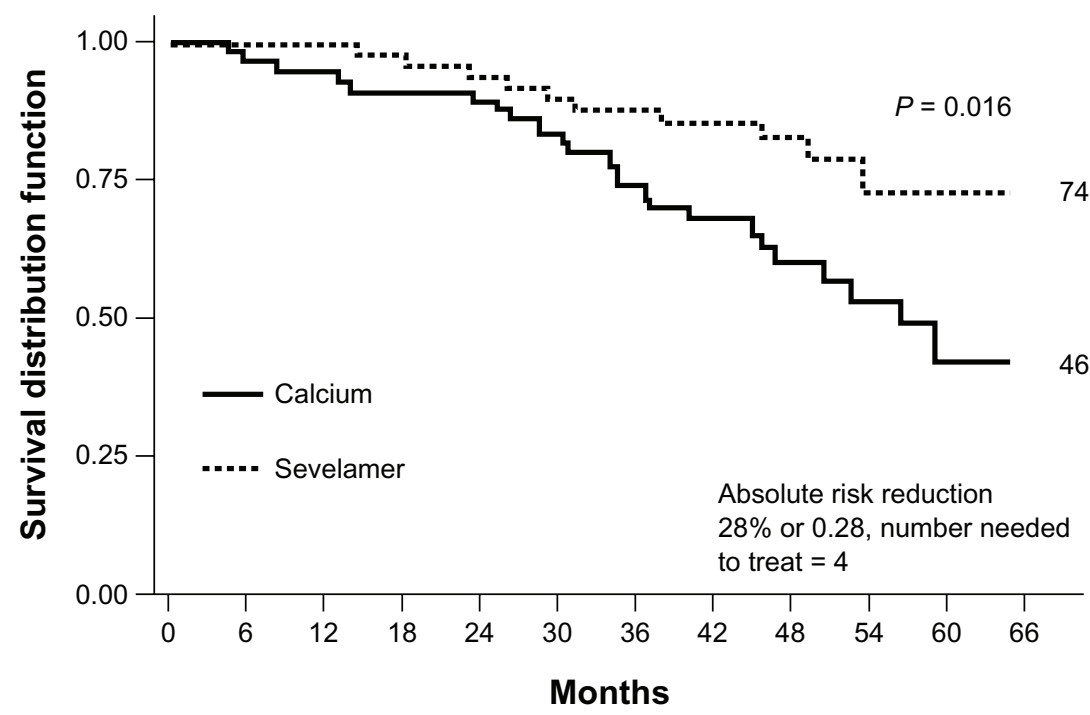

Figure 4 Calcium-free binders such as sevelamer are associated with reduced rates of mortality compared with calcium-based binders. Reprinted by permission from Macmillan publisher Ltd: Kidney Int. ${ }^{34}$ Copyright 2007. 
Table 2 Summary of phosphorus and protein content of selected foods according to US Department of Agriculture national nutrient database ${ }^{21}$

\begin{tabular}{|c|c|c|c|c|}
\hline Food & Common measure & $\begin{array}{l}\text { Phosphorus content } \\
\text { (mg) }\end{array}$ & $\begin{array}{l}\text { Protein content } \\
\text { (g) }\end{array}$ & $\begin{array}{l}\text { Phosphorus (mg)/ } \\
\text { protein (g) ratio }\end{array}$ \\
\hline Veal (leg) & $85 \mathrm{~g}$ & 212 & 31 & 6.8 \\
\hline Chicken (broiled) & $140 \mathrm{~g}$ & 259 & 35 & 7.4 \\
\hline Lamb (leg) & $85 \mathrm{~g}$ & 162 & 22 & 7.4 \\
\hline Beef (roasted) & $85 \mathrm{~g}$ & 200 & 26.4 & 7.6 \\
\hline Turkey (roasted) & $85 \mathrm{~g}$ & 208 & 24 & 8.7 \\
\hline Fish (cod, canned) & $85 \mathrm{~g}$ & 221 & 19.4 & $1 \mathrm{I} .4$ \\
\hline Pork & $85 \mathrm{~g}$ & 224 & 18 & 12.4 \\
\hline Crab & $85 \mathrm{~g}$ & 238 & 16.5 & 14.4 \\
\hline Salmon & $85 \mathrm{~g}$ & 280 & 17 & 16.5 \\
\hline Bread (white) & I slice & 25 & 3.4 & 7.3 \\
\hline Bagel (plain) & $31 / 2^{\prime \prime}$ & 68 & 7.5 & 9.0 \\
\hline Bread (mixed grain) & | slice & 46 & 2.6 & 17.7 \\
\hline Almonds & $28 \mathrm{~g}$ & 134 & 6.0 & 22.3 \\
\hline Pistachio & $28 \mathrm{~g}$ & 137 & 6.0 & 22.8 \\
\hline Walnuts & $28 \mathrm{~g}$ & 98 & 4.3 & 22.8 \\
\hline Biscuits & $21 / 2$ & 98 & 4.2 & 23.3 \\
\hline Cereals (Kellogg's $s^{\circledR}$ Raisin Bran) & $250 \mathrm{~mL}$ & 259 & 5.2 & 49.8 \\
\hline Cereals (General Mills) & $250 \mathrm{~mL}$ & 232 & 4.4 & 52.7 \\
\hline Egg, white raw & I large & 5 & 3.64 & 1.4 \\
\hline Egg, whole, fried & I large & 96 & 6.27 & 15.3 \\
\hline Cheese (Muenster) & $28 \mathrm{~g}$ & 133 & 6.64 & 20.0 \\
\hline Egg, yolk, raw & I large & 65 & 2.63 & 24.7 \\
\hline Cheese (American) & $28 \mathrm{~g}$ & 124 & 4.65 & 26.6 \\
\hline Yogurt (plain, low-fat) & $236 \mathrm{~mL}$ & 327 & 11.9 & 27.5 \\
\hline Milk (whole) & $250 \mathrm{~mL}$ & 222 & 7.86 & 28.2 \\
\hline Milk shake & $312 \mathrm{~mL}$ & 378 & 9.15 & 41.3 \\
\hline
\end{tabular}

phosphorus levels without risking malnutrition. In total, 13 patients with serum phosphorus $>4.0 \mathrm{mg} / \mathrm{dL}$ consumed one meal containing 8 ounces (225 g) of pasteurized liquid egg whites per day for 6 weeks. ${ }^{15}$ At the end of the study, twelve patients exhibited a significant reduction in mean serum phosphorus and a significant increase in mean serum albumin (Figure 5). ${ }^{15}$ Dietary phosphorus restriction for 3 months in chronic hemodialysis patients receiving a lowphosphorus and low-potassium whey protein concentrate to partially replace food protein also demonstrated a beneficial reduction in serum phosphorus and intact PTH without detrimental changes to nutritional status. ${ }^{40}$

Dietary counseling should encourage the consumption of foods with the least amount of inorganic phosphorus, low phosphorus-to-protein ratios, and adequate protein content, consistent with acceptable palatability. ${ }^{12}$ Differences in the source of dietary protein and the bioavailability of phosphorus can have a significant impact on serum phosphorus control. In predialysis $\mathrm{CKD}$ patients who ate a metabolic-laboratory vegetarian diet for just 1 week, serum phosphorus levels and fibroblast growth factor-23 levels were lower compared with patients consuming a meat diet with the same protein, calories, and phosphorus intake level. ${ }^{41}$ Other measures that should be encouraged include the use of selective over nonselective vitamin D activators to minimize intestinal phosphorus absorption, ${ }^{42}$ the diligent use of phosphorus binders to reduce the pill burden, and patient-friendly educational tools such as the concept of a dietary "phosphate unit" and its relationship with binder dose..$^{43}$ There is evidence that education on avoiding foods with phosphorus additives does contribute to better reduction in serum phosphorus levels versus control participants. ${ }^{44}$ For 3 months, participants received education on avoiding foods with phosphorus additives when purchasing groceries or visiting fast food restaurants, or continued to receive usual care. After 3 months, the decline in serum phosphorus levels was significantly greater among intervention versus control participants. Intervention participants also had statistically significant increases in reading ingredient lists and nutrition facts labels.

In teaching patients to take control of dietary phosphorus and protein intake, educators need to provide patients tools and demonstrate how to recognize and avoid inorganic phosphorus additives; how to select protein sources and achieve protein adequacy; and how to estimate the phosphorus 


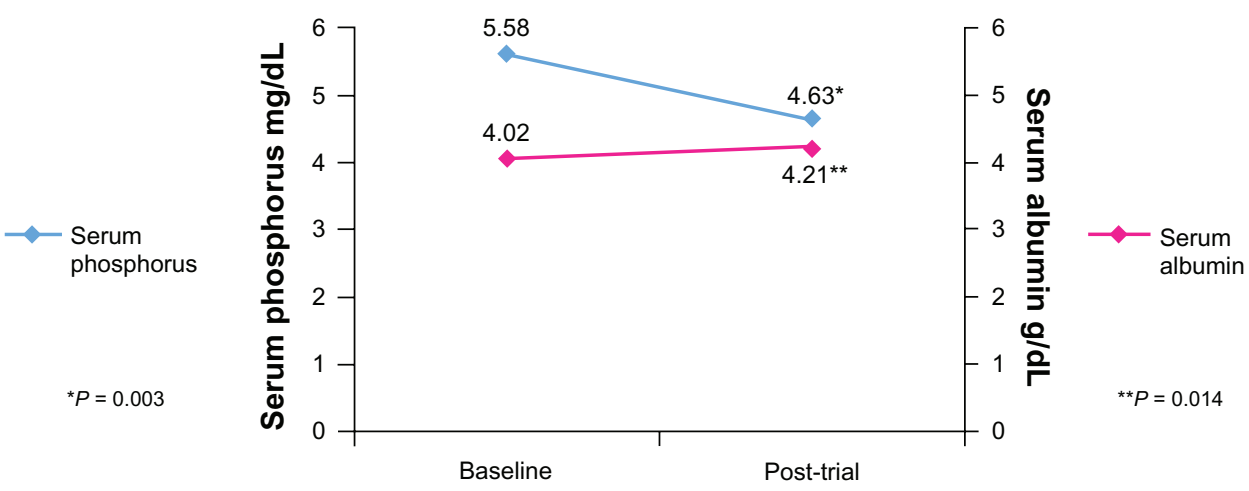

Figure $5 \mathrm{~A}$ pilot study in maintenance hemodialysis patients demonstrated the benefit of egg whites (I meal a day for 6 weeks) as a major protein source to provide a high protein/low phosphorus intake. Mean serum phosphorus decreased and mean serum albumin increased.

Data graphed de novo from Taylor et al. ${ }^{15}$

content of chosen foods. Glossaries of additives used in conjunction with label-reading (see Table 1 for an example) can help patients restrict consumption of phosphorus in processed and fast foods. Food charts and tables can help patients identify foods low in phosphorus. Reliable estimation of the phosphorus content of chosen foods is possible with the use of comprehensive labelling of phosphorus additives, and a "traffic light" scheme can help to simplify foods into "high," "intermediate," or "low" phosphorus content. ${ }^{45}$ Protein adequacy with lesser phosphorus burden can be facilitated by teaching patients cooking methods that reduce the phosphorus content while preserving protein content, such as boiling chicken or beef. ${ }^{46}$ In addition, motivational interview techniques that adopt a goal-oriented, patient-centered counseling approach are useful to encourage adherence to selected protein sources while emphasizing that dietary changes reduce the risk of mortality (Table 3 ). ${ }^{47}$ Regular monitoring of dietary phosphorus and protein intake can be achieved with food frequency questionnaires, which allow patients' difficulties with adherence to be easily identified. ${ }^{48}$ However, it has been proposed that food frequency questionnaires should be used for population-level dietary comparisons of patients rather than for individual assessment. ${ }^{49}$

Food fatigue is an emerging issue with specialized diets required in the management of chronic diseases, including CKD; food fatigue is a greater threat to dietary persistence than food allergies or intolerance. For instance, CKD patients required to consume specific foods, such as egg whites, may gradually become disinterested and less adherent. This can be overcome by diversifying the diet to include additional lowphosphorus, high-protein alternatives (eg, poultry). Variety is important, although choice should be limited where preference bias strongly affects nutritional content. ${ }^{50}$ Phosphorus binder use can also help overcome food fatigue by allowing patients' preferred mainstream foods while moderating their impact on serum phosphorus levels.

\section{Phosphorus binder use: education for concordance and adherence}

Current KDIGO guidelines recommend using phosphorus binders to treat hyperphosphatemia in patients with CKD stages $3-5 \mathrm{D} .{ }^{17}$ In contrast, the US Food and Drug Administration labelling of prescription phosphorus binders is specific to dialysis recipients with hyperphosphatemia. Incident dialysis patients receiving binders within the first 90 days experience a survival benefit. ${ }^{51}$ Similarly, in non-dialysis-dependent CKD, phosphorus binders have demonstrated a survival benefit in men with moderate and advanced disease (Figure 3). ${ }^{28}$ Some studies suggest that sevelamer may improve surrogate markers of CKD progression (eg, serum phosphorus, bicarbonate) and $\mathrm{CV}$ risk (eg, calcification) in predialysis patients; ${ }^{52,53}$ however, larger and more rigorous studies are warranted to confirm these findings. Phosphorus binders also allow greater dietary variety and liberalized protein intake, which may address both protein needs and food fatigue. Furthermore, the availability of tablet or powder formulations improves patient choice and versatility.

Since phosphorus binders need to be taken properly and consistently with meals and snacks to be effective, patient education is important in their successful use. Patients should be aware that phosphorus binders have to be taken at mealtimes, either during or towards the end of each meal. Patient dosing errors observed by dialysis teams have included failure to coordinate each dose with a meal, consuming the entire daily dose first thing in the morning before a dialysis session, or taking a fixed dose irrespective of food intake or phosphorus content. The daily pill burden in ESRD is one of the highest among chronic 
Table 3 The motivational interviewing tool kit ${ }^{47}$

\begin{tabular}{|c|c|c|c|}
\hline Motivational factor & Objective & Example & Follow-up \\
\hline I. Express empathy & $\begin{array}{l}\text { To establish rapport and avoid } \\
\text { resistance by demonstrating } \\
\text { understanding of the patient's } \\
\text { situation }\end{array}$ & $\begin{array}{l}\text { Patient expresses difficulty making } \\
\text { all these changes }\end{array}$ & $\begin{array}{l}\text { Remind the patient that current } \\
\text { levels put them at risk for more } \\
\text { serious diseases }\end{array}$ \\
\hline $\begin{array}{l}\text { 2. Roll with } \\
\text { resistance }\end{array}$ & $\begin{array}{l}\text { Avoid magnifying resistance } \\
\text { by allowing patient to explore } \\
\text { their barriers in a nonjudgmental } \\
\text { supportive manner }\end{array}$ & $\begin{array}{l}\text { Patient is reluctant to continue } \\
\text { medication since it is hard to } \\
\text { remember to take and they no } \\
\text { longer feel unwell }\end{array}$ & $\begin{array}{l}\text { Ask the patient where they see } \\
\text { themselves in } 6 \text { months if they } \\
\text { stop taking the medication }\end{array}$ \\
\hline $\begin{array}{l}\text { 3. Elicit/provide } \\
\text { reminder/elicit }\end{array}$ & $\begin{array}{l}\text { Find out what the patient already } \\
\text { knows, fill in the gaps or correct } \\
\text { misconceptions, and explore how } \\
\text { the change you suggest will fit into } \\
\text { the patient's life }\end{array}$ & $\begin{array}{l}\text { Elicit: Ask patient what they } \\
\text { know about managing their } \\
\text { CKD }\end{array}$ & $\begin{array}{l}\text { Reminder: For example, to take } \\
\text { statins and closely monitor blood } \\
\text { pressure } \\
\text { Elicit: "What do you think the } \\
\text { biggest barrier is for you right } \\
\text { now in managing this condition?" }\end{array}$ \\
\hline $\begin{array}{l}\text { 4. Support } \\
\text { autonomy }\end{array}$ & $\begin{array}{l}\text { To reduce resistance by assuring } \\
\text { patients you know you can't make } \\
\text { them do anything - it is their choice }\end{array}$ & $\begin{array}{l}\text { Emphasize to patient that } \\
\text { it is their choice but as their } \\
\text { doctor you are concerned if } \\
\text { they do not try medication }\end{array}$ & $\begin{array}{l}\text { Reiterate that it is the patient's } \\
\text { choice and they need to consider } \\
\text { all the options. Reassure patient } \\
\text { that if they do decide to try a } \\
\text { particular medication they will be } \\
\text { regularly monitored for side effects } \\
\text { and dose adjusted accordingly }\end{array}$ \\
\hline $\begin{array}{l}\text { 5. Explore } \\
\text { ambivalence }\end{array}$ & $\begin{array}{l}\text { Help patient consider pros and cons } \\
\text { of change in a relaxed yet } \\
\text { systematic manner }\end{array}$ & $\begin{array}{l}\text { Encourage a discussion about the } \\
\text { pros and cons, eg, eating egg whites } \\
\text { as part of a low-phosphorus diet }\end{array}$ & $\begin{array}{l}\text { Summarize current situation with } \\
\text { the patient and explain that the } \\
\text { benefits will outweigh the } \\
\text { potential drawbacks associated } \\
\text { with an egg-white diet }\end{array}$ \\
\hline $\begin{array}{l}\text { 6. Elicit change } \\
\text { talk }\end{array}$ & $\begin{array}{l}\text { To evoke the patient's reasons, } \\
\text { desire, ability, and need for change. } \\
\text { This predicts increased commitment } \\
\text { to the lifestyle change and good } \\
\text { clinical outcome }\end{array}$ & $\begin{array}{l}\text { "What makes it important to } \\
\text { you to start an exercise program?" } \\
\text { "What benefits would come from } \\
\text { losing weight?" "Why do you want } \\
\text { to quit smoking?" }\end{array}$ & $\begin{array}{l}\text { Remind patient of the benefits } \\
\text { of regular exercise and how well } \\
\text { it made them feel previously. } \\
\text { These measures will help patient } \\
\text { become a good role model for } \\
\text { their children and allow them } \\
\text { to play sports together }\end{array}$ \\
\hline $\begin{array}{l}\text { 7. Develop an } \\
\text { action plan }\end{array}$ & $\begin{array}{l}\text { To help the patient develop a plan } \\
\text { that is realistic and suitable for } \\
\text { their life }\end{array}$ & $\begin{array}{l}\text { Enquire about the next step for } \\
\text { the patient. Ask what they think they } \\
\text { can do or are willing to do to improve } \\
\text { health and make a difference }\end{array}$ & $\begin{array}{l}\text { Motivate patient to follow plan } \\
\text { and reiterate the steps agreed, } \\
\text { ie, eat more vegetables, avoid } \\
\text { fast foods, exercise more, etc }\end{array}$ \\
\hline
\end{tabular}

Abbreviation: CKD, chronic kidney disease.

diseases; phosphorus binders appear to be the largest single contributor. ${ }^{54}$ The high pill burden may affect adherence and the ability to maintain optimal phosphorus levels, ${ }^{55}$ which emphasizes the need to educate patients on the consequences of avoiding their medication, and to adapt binder use to the phosphorus content of meals. Binders are available in different dosage forms (eg, sevelamer carbonate tablets or powder for oral suspension; lanthanum carbonate chewable wafers); thus, patients who object to a particular dosing method should be given other options. In addition, motivational teaching methods can help patients overcome the pill burden, and reports from electronic medical records could identify the least adherent patients who require the most assistance. Medication therapy management programs can provide patients with ongoing adherence follow-up and problem-solving.

Recent educational initiatives by German nephrologist Martin Kuhlmann teach patients to estimate the phosphorus content of food and adjust the number of binder tablets accordingly at each meal. ${ }^{43,56,57}$ The Phosphate Education Program (PEP) provides simple training tools to instruct patients to eye-estimate meal phosphorus content based on newly defined phosphorus units (1 phosphorus unit $=100 \mathrm{mg} /$ serving), and to self-adjust phosphorus binder dosage accordingly. ${ }^{43,56}$ Phosphorus units can be assigned to whole food groups since similar food groups (eg, meat, seafood, vegetables) tend to have similar phosphorus content. Using this approach, patients do not have to memorize 
the phosphorus content of each individual food component but only the phosphorus unit value for a limited number of food groups. A set of 180 photo cards illustrating servings of different foods with their phosphorus unit values has been used to teach this approach to juvenile patients. ${ }^{57}$ After eye-estimating the phosphorus unit content of a meal, the patient self-adjusts the binder dose according to a binder/unit ratio prescribed by the nephrologist. The binder/unit ratio is titrated to the patient's individual needs by repeatedly measuring predialysis serum phosphorus levels and readjusting the binder/unit ratio until phosphorus targets are achieved. Experience with the PEP showed significantly improved control of hyperphosphatemia even without reducing dietary inorganic phosphorus intake. ${ }^{57}$

Other initiatives to improve concordance and adherence include increasing the frequency of consultations and dietitianto-patient ratio in dialysis clinics; monthly consultations for a period of 6 months and a ratio not exceeding 60 patients per dietitian have been shown to improve short-term phosphorus control. ${ }^{58}$ Furthermore, nutritional counseling should involve the entire dialysis team - not only the nephrologist and dietitian but also the nurse and social worker. Educational materials including pamphlets, videos, websites, and posters are useful tools to reinforce instruction for both patients and members of the renal team on how to optimize serum phosphorus levels. Another educational initiative includes dietitian-led education programs that test patients' general knowledge of phosphorus and phosphorus binders, and its impact on serum phosphorus concentrations. Small teaching sessions delivered by a single dietitian have been shown to significantly reduce serum phosphorus levels after 1 month. ${ }^{59}$

In summary, a variety of educational tools are available to improve the control of dietary phosphorus and adherence with phosphorus binders. Optimal phosphorus control requires an individualized approach with regular follow-up. This strategy should also be advocated in compliant patients achieving target phosphorus levels in order to provide encouragement and reinforce positive behavior.

\section{Calcium risk-awareness and appropriate intake}

In $\mathrm{CKD}$ patients, a positive calcium balance arises because intestinal absorption is greater than the kidney's capacity to excrete. Not all calcium sources are the same. Dietary calcium (especially dairy) coexists with phosphorus, protein, and fat; is absorbed more slowly than inorganic calcium supplements; and thus may be associated with less hypercalcemia and CV risk. ${ }^{60,61}$
Calcium intake within the Institute of Medicine (IOM) recommendations is important for health. The IOM's revised calcium guidelines recommend keeping total calcium intake below $2000 \mathrm{mg} /$ day for the general population; $1200 \mathrm{mg} /$ day is the recommended daily allowance for seniors (women $>50$ years and men $>70$ years) and $1000 \mathrm{mg} /$ day for all other adults. ${ }^{62}$ There is evidence, however, that total elemental calcium intake should be within 800-1200 mg/day to prevent calcium deficiency or calcium loading. Excessive calcium intake, especially from inorganic supplements, is associated with $\mathrm{CV}$ risk in the general public and patients with CKD. ${ }^{63} \mathrm{~A}$ recent meta-analysis in 29,000 postmenopausal women suggested that calcium supplementation increases risk of myocardial infarction and possibly stroke. ${ }^{64}$ The high media profile of osteoporosis has encouraged many Americans, particularly menopausal women, to consume over-the-counter calcium supplements on their own initiative to minimize the risk of fractures; some users erroneously assume that more calcium is better. Patients with CKD/ESRD should be encouraged to communicate openly to renal team members about any and all "self-prescribed" over-the-counter supplements, medications, or herbal products to avoid renal risks. Conversely, the renal team should educate patients about the risks associated with excessive calcium and teach patients how to obtain adequate and moderate calcium intake from foods rather than supplements.

Importantly, serum calcium concentration is regulated within narrow limits and thus is a poor guide to evaluate intake or calcium balance. Increased calcium intake significantly decreases active vitamin D and intact PTH levels but has no effect on serum calcium concentration. ${ }^{65}$ It is important for nephrologists to account for total calcium intake not only from diet or supplements but also from calcium-based binders, as binder calcium can also be systemically absorbed. ${ }^{66}$ In patients with CKD stages 3-5 and hyperphosphatemia, KDIGO advises restricting the dose of calcium-based phosphorus binders in the presence of hypercalcemia (persistent or recurrent), arterial calcification, adynamic bone disease, or persistently low $\mathrm{PTH} .{ }^{17}$ High serum calcium promotes vascular calcification by mechanisms that are not completely resolved. At any serum phosphorus level, higher serum calcium concentrations are associated with increased risk of death in dialysis patients. ${ }^{67}$ Studies have shown that calciumfree binders such as sevelamer reduce the progression of vascular calcification compared with calcium-based binders in dialysis ${ }^{32,68-73}$ and predialysis CKD patients, ${ }^{53,74,75}$ and thus merit consideration in patients with high $\mathrm{CV}$ risk. 


\section{Conclusion}

Recalcitrant hyperphosphatemia in patients with ESRD is related to dietary nonadherence (including overexposure to phosphorus additives and excessive reliance on high phosphorus-to-protein ratio animal sources), binder-related issues (pill burden and medication nonadherence, dosing errors, and adverse effects), and dialysis inadequacy (missed or shortened sessions). Balancing the risk versus benefit of dietary phosphorus for the management of hyperphosphatemia in CKD-MBD requires more attention to the restriction of bioavailable inorganic dietary phosphorus (eg, fewer processed and fast foods); a liberal protein intake balanced by choice of low-phosphate entrees and appropriate binder use; more attention to phosphorus-to-protein ratio; and reinforcement of non-dietary phosphorus control by appropriate binder use and adherence, improved dialysis adequacy, and possibly longer or more frequent dialysis. While dietary control in the CKD patient is largely focused on achieving phosphorus and protein targets, it is also important to consider the impact of a positive calcium load, which can contribute to hypercalcemia, vascular and soft tissue calcification, and increased $\mathrm{CV}$ risk.

Patient education and open patient/team dialogue on phosphorus and calcium management can improve concordance and adherence and empower patients to collaborate actively for optimal control of mineral metabolism throughout CKD/ ESRD. Emerging initiatives such as the PEP can provide a simple and effective means of identifying foods high in phosphorus and tailoring appropriate phosphorus binder use.

\section{Acknowledgments}

The author exerted scientific control throughout manuscript development, provided substantive revisions to the content, and approved the final published version, and acknowledges the writing assistance of Stuart Murray, MSc, of Envision Scientific Solutions, which was contracted by Sanofi to provide publication support services.

\section{Disclosure}

Dr Kalantar-Zadeh reports receiving honoraria and/or grants from Abbott, Amgen, DaVita, Fresenius, Sanofi, Otsuka, Shire, and Vifor, manufacturers of drugs or devices and/or providers of services for CKD patients. The author reports no other conflicts of interest in this work.

\section{References}

1. National Kidney Foundation. K/DOQI clinical practice guidelines for bone metabolism and disease in chronic kidney disease. Am J Kidney Dis. 2003;42(4 Suppl 3):S1-S201.
2. Block GA, Klassen PS, Lazarus JM, Ofsthun N, Lowrie EG, Chertow GM. Mineral metabolism, mortality, and morbidity in maintenance hemodialysis. J Am Soc Nephrol. 2004;15(8):2208-2218.

3. Kalantar-Zadeh K, Kuwae N, Regidor DL, et al. Survival predictability of time-varying indicators of bone disease in maintenance hemodialysis patients. Kidney Int. 2006;70(4):771-780.

4. Dhingra R, Sullivan LM, Fox CS, et al. Relations of serum phosphorus and calcium levels to the incidence of cardiovascular disease in the community. Arch Intern Med. 2007;167(9):879-885.

5. London GM, Guérin AP, Marchais SJ, Métivier F, Pannier B, Adda H. Arterial media calcification in end-stage renal disease: impact on allcause and cardiovascular mortality. Nephrol Dial Transplant. 2003; 18(9): 1731-1740

6. Moe SM, Chen NX. Pathophysiology of vascular calcification in chronic kidney disease. Circ Res. 2004;95(6):560-567.

7. Merjanian R, Budoff M, Adler S, Berman N, Mehrotra R. Coronary artery, aortic wall, and valvular calcification in nondialyzed individuals with type 2 diabetes and renal disease. Kidney Int. 2003;64(1):263-271.

8. Mizobuchi M, Towler D, Slatopolsky E. Vascular calcification: the killer of patients with chronic kidney disease. J Am Soc Nephrol. 2009;20(7):1453-1464.

9. Noori N, Kalantar-Zadeh K, Kovesdy CP, Bross R, Benner D, Kopple JD. Association of dietary phosphorus intake and phosphorus to protein ratio with mortality in hemodialysis patients. Clin J Am Soc Nephrol. 2010;5(4):683-692.

10. Kopple JD, Coburn JW. Metabolic studies of low protein diets in uremia. II. Calcium, phosphorus and magnesium. Medicine (Baltimore). 1973;52(6):597-607.

11. Uribarri J. Phosphorus homeostasis in normal health and in chronic kidney disease patients with special emphasis on dietary phosphorus intake. Semin Dial. 2007;20(4):295-301.

12. Kalantar-Zadeh K, Gutekunst L, Mehrotra R, et al. Understanding sources of dietary phosphorus in the treatment of patients with chronic kidney disease. Clin J Am Soc Nephrol. 2010;5(3):519-530.

13. Noori N, Sims JJ, Kopple JD, et al. Organic and inorganic dietary phosphorus and its management in chronic kidney disease. Iran J Kidney Dis. 2010;4(2):89-100.

14. Bell RR, Draper HH, Tzeng DY, Shin HK, Schmidt GR. Physiological responses of human adults to foods containing phosphate additives. J Nutr. 1977;107(1):42-50.

15. Taylor LM, Kalantar-Zadeh K, Markewich T, et al. Dietary egg whites for phosphorus control in maintenance haemodialysis patients: a pilot study. J Ren Care. 2011;37(1):16-24.

16. Kovesdy CP, Kalantar-Zadeh K. Why is protein-energy wasting associated with mortality in chronic kidney disease? Semin Nephrol. 2009;29(1):3-14.

17. Kidney Disease: Improving Global Outcomes (KDIGO) CKD-MBD Work Group. KDIGO clinical practice guideline for the diagnosis, evaluation, prevention, and treatment of Chronic Kidney DiseaseMineral and Bone Disorder (CKD-MBD). Kidney Int Suppl. 2009;(113): $\mathrm{S} 1-\mathrm{S} 130$

18. Gutiérrez OM, Anderson C, Isakova T, et al; CRIC Study Group. Low socioeconomic status associates with higher serum phosphate irrespective of race. J Am Soc Nephrol. 2010;21(11):1953-1960.

19. Calvo MS, Park YK. Changing phosphorus content of the US diet: potential for adverse effects on bone. J Nutr. 1996;126(Suppl 4): $1168 \mathrm{~S}-1180 \mathrm{~S}$.

20. González S, Flick GJ, O’Keefe SF, Duncan SE, McLean E, Craig SR. Composition of farmed and wild yellow perch (Perca flavescens). J Food Compost Anal. 2006;19(6-7):720-726.

21. Food and Nutrition Information Center. USDA National Nutrient Database for Standard Reference, Release 17. Available from: http:// www.nal.usda.gov/fnic/foodcomp/Data/SR17/wtrank/sr17a305.pdf. Accessed March 26, 2013.

22. Shinaberger CS, Greenland S, Kopple JD, et al. Is controlling phosphorus by decreasing dietary protein intake beneficial or harmful in persons with chronic kidney disease? Am J Clin Nutr. 2008;88(6):1511-1518. 
23. Oenning LL, Vogel J, Calvo MS. Accuracy of methods estimating calcium and phosphorus intake in daily diets. J Am Diet Assoc. 1988; 88(9):1076-1080.

24. Murphy-Gutekunst L. Hidden phosphorus in popular beverages: part 1 J Ren Nutr. 2005;15(2):e1-e6.

25. Murphy-Gutekunst L, Uribarri J. Hidden phosphorus-enhanced meats: part 3. J Ren Nutr. 2005;15(4):e1-e4.

26. Gotch FA, Panlilio F, Sergeyeva O, et al. A kinetic model of inorganic phosphorus mass balance in hemodialysis therapy. Blood Purif. 2003;21(1):51-57.

27. McCarley PB, Burrows-Hudson S. Chronic kidney disease and cardiovascular disease - using the ANNA Standards and Practice Guidelines to improve care. Part 1: the epidemiology of chronic kidney disease: the risk factors and complications that contribute to cardiovascular disease. Nephrol Nurs J. 2006;33(6):666-674.

28. Kovesdy CP, Kuchmak O, Lu JL, Kalantar-Zadeh K. Outcomes associated with phosphorus binders in men with non-dialysis-dependent $\mathrm{CKD}$. Am J Kidney Dis. 2010;56(5):842-851.

29. Peacock M. Calcium metabolism in health and disease. Clin J Am Soc Nephrol. 2010;5 Suppl 1:S23-S30.

30. Russo D, Palmiero G, De Blasio AP, Balletta MM, Andreucci VE. Coronary artery calcification in patients with CRF not undergoing dialysis. Am J Kidney Dis. 2004;44(6):1024-1030.

31. Goodman WG, Goldin J, Kuizon BD, et al. Coronary-artery calcification in young adults with end-stage renal disease who are undergoing dialysis. N Engl J Med. 2000;342(20):1478-1483.

32. Chertow GM, Burke SK, Raggi P; Treat to Goal Working Group. Sevelamer attenuates the progression of coronary and aortic calcification in hemodialysis patients. Kidney Int. 2002;62(1):245-252.

33. Hutchison AJ, Maes B, Vanwalleghem J, et al. Efficacy, tolerability, and safety of lanthanum carbonate in hyperphosphatemia: a 6-month, randomized, comparative trial versus calcium carbonate. Nephron Clin Pract. 2005;100(1):c8-c19.

34. Block GA, Raggi P, Bellasi A, Kooienga L, Spiegel DM. Mortality effect of coronary calcification and phosphate binder choice in incident hemodialysis patients. Kidney Int. 2007;71(5):438-441.

35. Suki WN, Zabaneh R, Cangiano JL, et al. Effects of sevelamer and calcium-based phosphate binders on mortality in hemodialysis patients Kidney Int. 2007;72(9):1130-1137.

36. Gutzwiller JP, Schneditz D, Huber AR, Schindler C, Garbani E, Zehnder CE. Increasing blood flow increases kt/V(urea) and potassium removal but fails to improve phosphate removal. Clin Nephrol. 2003; 59(2):130-136.

37. Leypoldt JK. Kinetics of beta2-microglobulin and phosphate during hemodialysis: effects of treatment frequency and duration. Semin Dial. 2005;18(5):401-408.

38. Walsh M, Manns BJ, Klarenbach S, Tonelli M, Hemmelgarn B, Culleton B. The effects of nocturnal compared with conventional hemodialysis on mineral metabolism: A randomized-controlled trial. Hemodial Int 2010;14(2):174-181.

39. Badve SV, McCormick BB. Phosphate balance on peritoneal dialysis. Perit Dial Int. 2008;28(Suppl 2):S26-S32.

40. Guida B, Piccoli A, Trio R, et al. Dietary phosphate restriction in dialysis patients: a new approach for the treatment of hyperphosphataemia. Nutr Metab Cardiovasc Dis. 2011;21(11):879-884.

41. Moe SM, Zidehsarai MP, Chambers MA, et al. Vegetarian compared with meat dietary protein source and phosphorus homeostasis in chronic kidney disease. Clin J Am Soc Nephrol. 2011;6(2):257-264.

42. Kalantar-Zadeh K, Kovesdy CP. Clinical outcomes with active versus nutritional vitamin D compounds in chronic kidney disease. Clin J Am Soc Nephrol. 2009;4(9):1529-1539.

43. Kuhlmann MK, Hoechst S, Landthaler I. Patient empowerment in the management of hyperphosphatemia. Int $J$ Artif Organs. 2007;30(11):1008-1013.

44. Sullivan C, Sayre SS, Leon JB, et al. Effect of food additives on hyperphosphatemia among patients with end-stage renal disease: a randomized controlled trial. JAMA. 2009;301(6):629-635.
45. Ritz E, Hahn K, Ketteler M, Kuhlmann MK, Mann J. Phosphate additives in food - a health risk. Dtsch Arztebl Int. 2012;109(4):49-55.

46. Cupisti A, D’Alessandro C, Baldi R, Barsotti G. Dietary habits and counseling focused on phosphate intake in hemodialysis patients with hyperphosphatemia. J Ren Nutr. 2004;14(4):220-225.

47. Linden A, Biuso TJ, Butterworth SW. Help patients with chronic kidney disease stave off dialysis. J Fam Pract. 2010;59(4):212-219.

48. Kalantar-Zadeh K, Kovesdy CP, Bross R, et al. Design and development of a dialysis food frequency questionnaire. J Ren Nutr. 2011;21(3): 257-262.

49. Bross R, Noori N, Kovesdy CP, et al. Dietary assessment of individuals with chronic kidney disease. Semin Dial. 2010;23(4):359-364.

50. Vicens C, Wang C, Olabi A, Jackson P, Hunter J. Optimized bioregenerative space diet selection with crew choice. Habitation (Elmsford). 2003;9(1-2):31-39.

51. Isakova T, Gutiérrez OM, Chang Y, et al. Phosphorus binders and survival on hemodialysis. J Am Soc Nephrol. 2009;20(2):388-396.

52. Ketteler M, Rix M, Fan S, et al. Efficacy and tolerability of sevelamer carbonate in hyperphosphatemic patients who have chronic kidney disease and are not on dialysis. Clin J Am Soc Nephrol. 2008;3(4):1125-1130.

53. Russo D, Miranda I, Ruocco C, et al. The progression of coronary artery calcification in predialysis patients on calcium carbonate or sevelamer. Kidney Int. 2007;72(10):1255-1261.

54. Chiu YW, Teitelbaum I, Misra M, de Leon EM, Adzize T, Mehrotra R. Pill burden, adherence, hyperphosphatemia, and quality of life in maintenance dialysis patients. Clin J Am Soc Nephrol. 2009;4(6):1089-1096.

55. Tomasello S, Dhupar S, Sherman RA. Phosphate binders, K/DOQI guidelines, and compliance: The unfortunate reality. Dial Transplant. 2004;33(5):236-242.

56. Kuhlmann MK. Practical approaches to management of hyperphosphatemia: can we improve the current situation? Blood Purif. 2007;25(1):120-124.

57. Ahlenstiel T, Pape L, Ehrich JH, Kuhlmann MK. Self-adjustment of phosphate binder dose to meal phosphorus content improves management of hyperphosphataemia in children with chronic kidney disease. Nephrol Dial Transplant. 2010;25(10):3241-3249.

58. Morey B, Walker R, Davenport A. More dietetic time, better outcome? A randomized prospective study investigating the effect of more dietetic time on phosphate control in end-stage kidney failure haemodialysis patients. Nephron Clin Pract. 2008;109(3):c173-c180.

59. Reddy V, Symes F, Sethi N, et al. Dietitian-led education program to improve phosphate control in a single-center hemodialysis population. J Ren Nutr. 2009;19(4):314-320.

60. Bolland MJ, Grey A, Avenell A, Gamble GD, Reid IR. Calcium supplements with or without vitamin D and risk of cardiovascular events: reanalysis of the Women's Health Initiative limited access dataset and meta-analysis. BMJ. 2011;342:d2040.

61. Reid IR, Bolland MJ, Sambrook PN, Grey A. Calcium supplementation: balancing the cardiovascular risks. Maturitas. 2011;69(4):289-295.

62. Institute of Medicine of the National Academies. Dietary reference intakes for calcium and vitamin D. Report Brief 2010; 1-4. Accessed March 262013 http://www.iom.edu/ /media/Files/Report\%20 Files/2010/Dietary-Reference-Intakes-for-Calcium-and-Vitamin-D/ Vitamin\%20D\%20and\%20Calcium\%202010\%20Report\%20Brief. pdf. Accessed March 1, 2013.

63. Reid IR, Bolland MJ. Calcium supplements: bad for the heart? Heart. 2012;98(12):895-896.

64. Bolland MJ, Grey A, Gamble GD, Reid IR. Calcium and vitamin D supplements and health outcomes: a reanalysis of the Women's Health Initiative (WHI) limited-access data set. Am J Clin Nutr. 2011; 94(4):1144-1149.

65. Spiegel DM, Brady K. Calcium balance in normal individuals and in patients with chronic kidney disease on low- and high-calcium diets. Kidney Int. 2012;81(11):1116-1122.

66. Langman CB, Cannata-Andiá JB. Calcium in chronic kidney disease: myths and realities. Introduction. Clin J Am Soc Nephrol. 2010; 5 Suppl 1:S1-S2. 
67. Tentori F, Blayney MJ, Albert JM, et al. Mortality risk for dialysis patients with different levels of serum calcium, phosphorus, and PTH: the Dialysis Outcomes and Practice Patterns Study (DOPPS). Am J Kidney Dis. 2008;52(3):519-530.

68. Asmus HG, Braun J, Krause R, et al. Two year comparison of sevelamer and calcium carbonate effects on cardiovascular calcification and bone density. Nephrol Dial Transplant. 2005;20(8):1653-1661.

69. Block GA, Spiegel DM, Ehrlich J, et al. Effects of sevelamer and calcium on coronary artery calcification in patients new to hemodialysis. Kidney Int. 2005;68(4):1815-1824.

70. Braun J, Asmus HG, Holzer H, et al. Long-term comparison of a calcium-free phosphate binder and calcium carbonate - phosphorus metabolism and cardiovascular calcification. Clin Nephrol. 2004;62(2): 104-115.

71. Chertow GM, Raggi P, McCarthy JT, et al. The effects of sevelamer and calcium acetate on proxies of atherosclerotic and arteriosclerotic vascular disease in hemodialysis patients. Am J Nephrol. 2003;23(5): 307-314.
72. Kakuta T, Tanaka R, Hyodo T, et al. Effect of sevelamer and calciumbased phosphate binders on coronary artery calcification and accumulation of circulating advanced glycation end products in hemodialysis patients. Am J Kidney Dis. 2011;57(3):422-431.

73. Shantouf R, Ahmadi N, Flores F, et al. Impact of phosphate binder type on coronary artery calcification in hemodialysis patients. Clin Nephrol. 2010;74(1):12-18.

74. Caglar K, Yilmaz MI, Saglam M, et al. Short-term treatment with sevelamer increases serum fetuin-a concentration and improves endothelial dysfunction in chronic kidney disease stage 4 patients. Clin J Am Soc Nephrol. 2008;3(1):61-68.

75. Di Iorio B, Bellasi A, Russo D; INDEPENDENT Study Investigators. Mortality in kidney disease patients treated with phosphate binders: a randomized study. Clin J Am Soc Nephrol. 2012;7(3):487-493.

\section{Publish your work in this journal}

Lung Cancer: Targets and Therapy is an international, peer-reviewed, open access journal focusing on lung cancer research, identification of therapeutic targets and the optimal use of preventative and integrated treatment interventions to achieve improved outcomes, enhanced survival and quality of life for the cancer patient. Specific topics covered in the journal include: Epidemiology, detection and screening; Cellular research and biomarkers; Identification of biotargets and agents with novel

Submit your manuscript here: http://www.dovepress.com/lung-cancer-targets--therapy-journa mechanisms of action; Optimal clinical use of existing anticancer agents, including combination therapies; Radiation and surgery; Palliative care; Patient adherence, quality of life, satisfaction; Health economic evaluations. The manuscript management system is completely online and includes a very quick and fair peer-review system. Visit http://www.dovepress.com/testimonials.php to read real quotes from published authors. 